\title{
Prokrastinasi Akademik Ditinjau Dari Kontrol Diri Pada Siswa-Siswi SMA Swasta Ar-Rahman Medan
}

\section{Academic Procrastination Viewed From Self Control On Students At SMA Swasta Ar-Rahman MEDAN}

\author{
Dewinta Widyastari(1)*, Diny Atrizka(2), Beby Ramadhani(3), Devi S Damanik(4) \\ Fakultas Psikologi, Universitas Prima Indonesia, Indonesia
}

Diterima : 06 Juli 2020; Disetujui : 25 Juli 2020; Dipublish : 29 Agustus 2020

*Corresponding author: E-mail: dewintawidytari2@gmail.com

\begin{abstract}
Abstrak
Penelitian ini bertujuan untuk mengetahui hubungan antara kontrol diri dan prokrastinasi akademik. Hipotesis yang diajukan dalam penelitian ini adalah ada hubungan negatif antara kontrol diri dengan prokrastinasi akademik dengan asumsi semakin tinggi kontrol diri yang dimiliki siswa-siswi, maka semakin rendah prokrastinasi akademik yang dimiliki siswa-siswi dan sebaliknya. Subjek penelitian yang digunakan dalam penelitian ini adalah siswa-siswi SMA Swasta Ar-Rahman Medan sebanyak 127 orang yang dipilih dengan metode disproportionate stratified random sampling. Data diperoleh dari skala untuk mengukur prokrastinasi akademik dan kontrol diri. Perhitungan dilakukan dengan melalui uji prasyarat analisis (uji asumsi) yang terdiri dari uji normalitas dan uji linearitas. Analisis data yang digunakan adalah menggunakan korelasi Product Moment melalui bantuan SPSS 17 for Windows. Hasil analisis data menunjukkan koefesien korelasi sebesar -0.698 dengan p sebesar 0,000 ( $p<0,05)$. Artinya ada hubungan negatif antara kontrol diri dengan prokrastinasi akademik. Hasil penelitian ini menunjukkan bahwa sumbangan yang diberikan variabel kontrol diri terhadap prokrastinasi akademik adalah sebesar 48.7 persen dan selebihnya 51.3 persen dipengaruhi oleh faktor lain. Dari hasil penelitian ini dapat ditarik kesimpulan bahwa hipotesis penelitian ada hubungan negatif antara kontrol diri dan prokrastinasi akademik, dapat diterima.
\end{abstract}

Kata Kunci: Kontrol Diri; Prokrastinasi Akademik.

\begin{abstract}
This study aims to determine the correlation between self control and academic procrastination. The hypothesis of this study stated that there was a negative correlation between self control and academic procrastination, with the assumption that the higher self control of the student's, the lower the academic procrastination of the student's and conversely. The subjects of the study are 127 student's at SMA Swasta Ar-Rahman Medan who were selected by the this disproportionate stratified random sampling method. Data were obtained from a scale for measuring self control and academic procrastination. The calculation was performed by means of testing requirements analysis (assumption) that consists of a test for normality and linearity. The analysis of the data was performed using product moment corellation with SPSS 17 for Windows. The results of data analysis showed that the correlation coefficient was -0.689 with $p 0.000$ $(p<0.05)$. This means that there is a negative correlation between self control and academic procrastination. The results indicated that the contribution given to the variable of self control and academic procrastination is by 48.7 percent and the remaining 51.3 percent is affected by other factors not exaited. Based on the results, it was concluded that the hypothesis was accepted there was a negative relationship between self control and academic procrastination. Keywords: Self Control; Academic Procrastination.
\end{abstract}

Rekomendasi mensitasi :

Widyastari, D., Atrizka, D., Ramashani, B., \& Damanik, S,D. (2020), Prokrastinasi Akademik Ditinjau Dari Kontrol Diri Pada Siswa-Siswi SMA Swasta AR-Rahman Medan, Jurnal Penelitian Pendidikan, Psikologi dan Kesehatan (J-P3K), 1 (2): 82-91. 


\section{PENDAHULUAN}

Pendidikan sangatlah penting di setiap Negara, sebab pendidikan merupakan upaya untuk meningkatkan kualitas sumber daya manusia yang bermutu sehingga dapat hidup mandiri, produktif, dan bertanggung jawab. Pendidikan disebut juga sebagai jalan untuk mengubah nasib manusia dari satu jenjang ke jenjang yang lebih tinggi.

Menurut Undang-Undang Sistem Pendidikan Nasional No. 20 Tahun 2003 (Sisdiknas, 2014) pendidikan adalah usaha sadar dan terencana untuk mewujudkan suasana belajar dan proses pembelajaran agar peserta didik secara aktif mengembangkan potensi dirinya untuk memiliki kekuatan spiritual keagamaan, pengendalian diri, kepribadian, kecerdasan, akhlak mulia, serta keterampilan yang diperlukan dirinya dan masyarakat.

Sagala (2013) menambahkan pendidikan adalah menuntun segala kekuatan kodrat yang ada pada anak-anak agar mereka sebagai manusia dan sebagai anggota masyarakat dapat mencapai keselamatan dan kebahagiaan setinggitingginya. Pendidikan yang berkualitas sangat diperlukan untuk mendukung terciptanya manusia yang cerdas serta mampu bersaing di masa mendatang.

Pendidikan yang berkualitas sangat diperlukan untuk mendukung terciptanya manusia yang cerdas serta mampu bersaing di masa mendatang. Pendidikan dapat mengembangkan potensi peserta didik, sehingga peserta didik mampu menghadapi dan memecahkan problema kehidupan yang dihadapi, dapat mendukung pembangunan bangsa di masa mendatang. Pendidikan tersebut akan berguna ketika seseorang memasuki kehidupan di masyarakat dan dunia kerja, karena mereka harus mampu menerapkan apa yang dipelajari di sekolah untuk menghadapi problema yang terjadi dalam kehidupan sehari-hari baik yang terjadi saat ini maupun yang akan datang.

Dalam proses pendidikan, siswalah yang menjadi sasaran utama bagi para pendidik. Siswa sebagai peserta didik yang terdaftar dan belajar di suatu lembaga sekolah tertentu, baik di sekolah dasar (SD), sekolah menengah pertama (SMP), maupun sekolah menengah atas (SMA). Menurut Sumanto (2014) masa usia sekolah dasar disebut juga masa intelektual dimana masa usia sekolah dasar terbagi dua yaitu masa kelas rendah (7-9) tahun dan masa kelas tinggi (10-12) tahun, masa usia sekolah menengah bertepatan dengan masa remaja yang terbagi ke dalam tiga bagian yaitu masa remaja awal, masa remaja madya, dan masa remaja akhir atau masa usia mahasiswa (18-25) tahun.

Menurut Hurlock (dalam Ali \& Asrori, 2011) menyebutkan bahwa remaja merupakan masa peralihan antara masa anak dan masa dewasa yang berjalan antara umur 11 tahun sampai 21 tahun. Remaja berasal dari kata latin "adolensence" yang berarti tumbuh atau tumbuh menjadi dewasa. Istilah adolensence mempunyai arti yang lebih luas lagi mencakup kematangan mental, emosional, sosial, dan fisik.

Pada saat masa peralihan, remaja tentunya perlu banyak belajar dalam segala hal yang mempengaruhi kehidupannya kelak. Belajar merupakan tugas utama seorang pelajar atau siswa, 
namun tidak semua siswa memiliki cara belajar yang baik, khususnya dalam pengelolaan waktu. Ketika seorang pelajar tidak bisa memanfaatkan waktu dengan baik, membuang-buang waktu dengan siasia, suka menunda-nunda pekerjaan dengan melakukan kegiatan yang kurang bermanfaat sehingga tugas terbengkalai dan tidak maksimal dalam menyelesaikan tugas, maka berpotensi terhambatnya siswa dalam meraih kesuksesan dan cenderung mendapatkan kegagalan. Waktu belajar yang kurang baik menyebabkan siswa sering melakukan penundaan dalam mengerjakan tugastugas akademik.

Pernyataan di atas didukung dengan hasil observasi yang telah dilaksanakan di SMA Swasta Ar-Rahman Medan, dimana peneliti melakukan wawancara kepada beberapa siswa-siswi dan ditemukan bahwa siswa-siswi disana sering menunda-nunda untuk mengerjakan atau mengumpulkan pekerjaan rumah (PR). Mereka menunda untuk mengerjakan atau mengumpulkan tugas, dikarenakan banyaknya tugas yang diberikan oleh guru setiap mata pelajaran, sehingga membuat mereka kebingungan untuk mengerjakan tugas yang mana terlebih dahulu dikerjakan. Selain banyaknya tugas yang diberikan ada juga faktor-faktor lain seperti, ajakan teman untuk lebih memilih bermain dibandingkan mengerjakan tugas dari sekolah, tugas dari mata pelajaran yang tidak mereka suka, kesulitan dalam menyelesaikan tugas tersebut, kurang yakin dalam menyelesaikan tugas tersebut, dan sudah kecanduan internet atau bermain game. Akibatnya mereka sering mendapatkan hukuman dari guru karena tidak mengerjakan atau mengumpulkan PR. Hukumannya berupa tidak diberi ijin untuk masuk kelas selama 1 les saat pelajaran itu berlangsung, berdiri di depan kelas atau membersihkan toilet sekolah.

Seseorang yang mempunyai kesulitan dalam mengerjakan tugas akademik dengan batas waktu yang telah ditentukan dan gagal dalam menyelesaikan tugas akademiknya dengan batas waktu tertentu, dikatakan sebagai seorang yang melakukan prokrastinasi akademik. Menurut Yong (dalam Hidayah \& Atmoko, 2014) berpendapat bahwa prokrastinasi akademik adalah kecenderungan irasional untuk menunda memulai atau menyelesaikan tugas akademik.

Millgram (dalam Gufron \& Risnawita, 2016) mengatakan bahwa prokrastinasi adalah perilaku yang spesifik, yang meliputi suatu perilaku yang melibatkan unsur penundaan, baik untuk memulai maupun menyelesaikan suatu tugas atau aktivitas, menghasilkan akibatakibat lain yang lebih jauh, misalnya keterlambatan menyelesaikan tugas maupun kegagalan dalam mengerjakan tugas, melibatkan suatu tugas yang dipersepsikan oleh pelaku prokrastinasi sebagai tugas yang penting untuk dikerjakan. Misalnya tugas kantor, tugas sekolah maupun tugas rumah tangga, menghasilkan keadaan emosional yang tidak menyenangkan, misalnya perasaan cemas, perasaan bersalah, marah, panik dan sebagainya.

Berdasarkan hasil penelitian yang dilakukan oleh para ahli sebelumnya menunjukkan bahwa kontrol diri merupakan salah satu faktor yang 
mempengaruhi prokrastinasi akademik pada pelajar. Hal ini dibuktikan pada penelitian yang dilakukan oleh Fajarwati (2015), dimana ketika individu yang memiliki self-control yang tinggi berarti mampu mengontrol tindakan pada perilaku yang membuat dirinya berkembang lebih baik dan dapat mempergunakan waktu yang ada sebagaimana mestinya atau sesuai dengan tujuan yang ditetapkan. Bila perannya sebagai mahasiswa tingkat akhir mengerjakan skripsi, maka mahasiswa akan memfokuskan tindakannya pada perilaku yang mendukung proses penyusunan skripsi.

Hasil penelitian diatas sejalan dengan penelitian lainnya, yang dilakukan oleh Purwanti, dkk (2016) terhadap 53 peserta didik kelas X. Penelitian ini menunjukkan bahwa terdapat pengaruh antara kontrol diri dengan prokrastinasi peserta didik kelas X SMA Negeri 1 Sungai Ambawang, dengan $r_{\text {hitung }}=-0,708$ berada pada kategori "kuat". Besarnya pengaruh kontrol diri terhadap prokrastinasi akademik 50\%, terdapat pengaruh negatif yang signifikan. Artinya semakin tinggi kontrol diri maka semakin rendah prokrastinasi akademik peserta didik, dan sebaliknya semakin rendah kontrol diri maka semakin tinggi prokrastinasi akademik peserta didik.

Ketika individu yang memiliki selfcontrol yang tinggi berarti mampu mengontrol tindakan pada perilaku yang membuat dirinya berkembang lebih baik dan dapat mempergunakan waktu yang ada sebagaimana mestinya atau sesuai dengan tujuan yang ditetapkan. Calhoun dan Acocella (dalam Ghufron \& Risnawita, 2016) mendefinisikan kontrol diri sebagai pengaturan proses-proses fisik, psikologis, dan perilaku seseorang, dengan kata lain serangkaian proses yang akan membentuk dirinya sendiri.

Menurut Lazarus (dalam Thalib, 2010) kontrol diri menggambarkan keputusan individu melalui pertimbanga kognitif untuk menyatukan perilaku yang telah disusun guna meningkatkan hasil dan tujuan tertentu sebagaimana yang diinginkan.

Adapun aspek-aspek prokrastinasi akademik dari Ferrari (dalam Ghufron \& Risnawita, 2016) diantaranya yaitu penundaan untuk memulai maupun menyelesaikan tugas, dimana procrastinator mengerti sekali bahwa tugas yang tengah dihadapinya harus segera diselesaikan dan berguna untuk dirinya, akan tetapi prokrastinator memilih untuk menunda dalam mengerjakan maupun menyelesaikan tugasnya hingga selesai.

Keterlambatan dalam mengerjakan tugas yang diberikan, prokrastinator memerlukan waktu yang lebih lama daripada waktu yang dibutuhkan pada umumnya dalam mengerjakan tugas yang diberikan. Mereka menghabiskan banyak waktu untuk mempersiapkan diri secara berlebihan, dan melakukan hal-hal yang tidak diperlukan dalam penyelesaian suatu tugas tanpa memperhitungkan batasan waktu yang dimilikinya.

Ketidaksesuaian/ kesenjangan waktu antara rencana dan kinerja aktual, procrastinator memiliki kesulitan untuk melakukan sesuatu sesuai dengan batas waktu yang telah ditentukan sebelumnya.

Melakukan aktivitas lain yang lebih menyenangkan, prokrastinator dengan sengaja tidak segera melakukan tugas 
yang diberikan, akan tetapi menggunakan waktu yang dimilikinya untuk melakukan aktivitas lain yang dipandang lebih menyenangkan dan mendatangkan hiburan, seperti membaca, menonton, mengobrol, berekreasi, mendengarkan musik, dan sebagainya sehingga membuang-buang waktu yang dimilikinya.

Ada lima faktor-faktor yang mempengaruhi prokrastinasi akademik antara lain Efikasi Diri penelitian yang dilakukan oleh Afriyeni, dkk (2014), yang kedua Dukungan Sosial Orang Tua penelitian yang dilakukan oleh Safitri (2018), yang ketiga Konsep Diri penelitian yang dilakukan oleh Khotimah, dkk (2016), yang keempat Motivasi Belajar penelitian yang dilakukan oleh Nitami, dkk (2015), dan yang kelima Regulasi Diri penelitian yang dilakukan oleh Fitriya dan Lukmawati (2016).

Selanjutnya untuk kontrol diri menggunakan tiga aspek dari Ghufron dan Risnawita (2016) yaitu yang pertama kontrol perilaku (behavior control) merupakan kesiapan tersedianya suatu respon yang dapat secara langsung memengaruhi atau memodifikasi suatu keadaan yang tidak menyenangkan, yang kedua kontrol kognitif (cognitve control) merupakan kemampuan individu dalam mengolah informasi yang tidak diinginkan dengan cara menginterprtasi, menilai, atau menghubungkan suatu kejadian dalam suatu erangka kognitif sebagai adaptasi psikologis atau mengurangi tekanan, yang ketiga mengontrol keputusan (decesional control) merupakan kemampuan seseorang untuk memilih hasil atau suatu tindakan berdasarkan pada sesuatu yang diyakini atau disetujuinya.
Tujuan penelitian ini adalah untuk mengetahui hubungan antara kontrol diri dengan prokrastinasi akademik pada siswa-siswi yang bersekolah di SMA Swasta Ar-Rahman Medan.

\section{METODE PENELITIAN}

Variabel yang digunakan dalam penelitian ini adalah variabel tergantung yaitu prokrastinasi akademik dan variabel bebas yaitu kontrol diri.

Prokrastinasi akademik adalah suatu kebisaan menunda-nunda untuk memulai ataupun menyelesaikan tugas akademik yang tidak ada tujuannya dan menghindarinya dari hari ke hari. Kontrol diri (self-control) adalah kemampuan seseorang dalam mengendalikan tubuh, pikiran atau perilaku pada diri sendiri untuk menjadi yang lebih baik.

Sampel dalam penelitian ini adalah siswa-siswi SMA Swasta Ar-Rahman Medan yang berjumlah 200 orang. Jumlah sampel di ambil berdasarkan ketentuan yang di ungkap oleh Isaac dan Michael dengan hasil perhitungan sampel minimal sebanyak 127 orang dengan persentasi kesalahan 5\% (Sugiyono, 2016).

Teknik pengambilan sampel yang digunakan dalam penelitian ini yaitu Dispropotionate Stratified Random Sampling. Sejalan dengan hal tersebut, Prasetyo dan Jannah (2013) menambahkan bahwa teknik pengambilan sampel jenis dispropotionate stratified random sampling dilakukan menggunakan rumus sebagai berikut:

Sampel $=\frac{\text { Populasi Kelas }}{\text { Total Populasi Keseluruhan }} \times$ Jumlah Sampel Yang Ditentukan 
Tabel 1. Perincian Jumlah Subjek Penelitian

\begin{tabular}{llll}
\hline No. & Kelas & $\begin{array}{l}\text { Jumlah } \\
\text { siswa }\end{array}$ & Jumlah Sampel \\
\hline 1 & X IPA & 26 & $26 / 200 \times 127=16$ \\
& X IPS & 26 & $26 / 200 \times 127=16$ \\
2 & XI IPA & 30 & $30 / 200 \times 127=19$ \\
& XI IPS & 30 & $30 / 200 \times 127=19$ \\
3 & XII IPA 1 & 26 & $26 / 200 \times 127=17$ \\
& XII IPA 2 & 26 & $26 / 200 \times 127=17$ \\
& XII IPS & 36 & $36 / 200 \times 127=23$ \\
\hline Jumlah & & 200 & 127 siswa
\end{tabular}

Metode penelitian yang digunakan untuk mendapatkan data yang diperlukan dalam penelitian ini adalah metode skala.

Teknik analisis yang digunakan untuk menganalisis data hasil penelitian ini adalah teknik korelasi Pearson Product Moment dengan menggunakan program SPSS 17 for windows.

\section{HASIL DAN PEMBAHASAN}

Uji normalitas dilakukan agar dapat mengetahui apakah setiap variabel penelitian telah menyebar secara normal atau tidak. Uji normalitas sebaran menggunakan uji Kolmogorov Smirnov Test. Data dikatakan berdistribusi normal jika p > 0.05 (Priyatno, 2011). Uji normalitas yang dilakukan terhadap variabel prokrastinasi akademik diperoleh koefisien $\mathrm{KS}-\mathrm{Z}=0.483$ dengan Sig sebesar 0.974 untuk uji 2 (dua) arah dan Sig sebesar 0.487 untuk uji 1 (satu) arah (p > 0.05), yang berarti bahwa data pada variabel prokrastinasi akademik memiliki sebaran atau berdistribusi normal. Uji normalitas pada variabel kontrol diri diperoleh koefisien KS-Z $=0.605$ dengan Sig sebesar 0.858 untuk uji 2 (dua) arah dan Sig sebesar 0.429 untuk uji 1 (satu) arah ( $\mathrm{p}>0.05$ ), yang berarti bahwa data pada variabel kontrol diri memiliki sebaran atau berdistribusi normal.

Tabel 2. Rangkuman Hasil Perhitungan Uji Normalitas Sebaran

\begin{tabular}{lllll}
\hline Variabel & SD & KS-Z & Sig & Ket. \\
\hline $\begin{array}{l}\text { Prokrastina } \\
\text { si Akademik }\end{array}$ & 15.385 & 0.483 & 0.487 & normal \\
& & & & \\
Kontrol Diri & 11.000 & 0.605 & 0.429 & normal \\
\hline
\end{tabular}

Uji linearitas digunakan untuk mengetahui apakah distribusi data penelitian yaitu kontrol diri dan prokrastinasi akademik memiliki hubungan linear Uji F (Anova). Variabel kontrol diri dan prokrastinasi akademik dikatakan memiliki hubungan linear jika $\mathrm{p}$ $<0.05$.

\begin{tabular}{lcll}
\multicolumn{4}{l}{ Tabel 3. Linieritas Hubungan } \\
\hline Variabel & F & Sig & Ket. \\
\hline $\begin{array}{l}\text { Prokrastinasi } \\
\text { Akademik }\end{array}$ & 130.593 & 0.000 & Linear \\
*Kontrol Diri & & & \\
\hline
\end{tabular}

Berdasarkan Tabel 3 dapat dikatakan bahwa variabel kontrol diri dan prokrastinasi akademik memiliki hubungan linear. Hal ini terlihat dari nilai sig yang diperoleh yaitu 0.000 maka $\mathrm{p}<$ 0.05 , dapat disimpulkan bahwa kedua variabel memiliki hubungan linear dan telah memenuhi syarat untuk dilakukan analisa korelasi Product Moment.

Tabel 4. Perbandingan Data Empirik dan Hipotetik Prokrastinasi Akademik

\begin{tabular}{lcl}
\hline Variabel & Empirik & Hipotetik \\
\hline $\begin{array}{l}\text { Prokrastinasi } \\
\text { Akademik }\end{array}$ & 96.37 & 100 \\
\hline
\end{tabular}

Hasil analisis untuk skala prokrastinasi akademik diperoleh mean empirik < mean hipotetik yaitu 96.37 < 100 maka dapat disimpulkan bahwa 
prokrastinasi akademik pada subjek penelitian lebih rendah daripada populasi pada umumnya.

Tabel 5. Kategorisasi Prokrastinasi Akademik

\begin{tabular}{lllll}
\hline Variabel & $\begin{array}{l}\text { Rentang } \\
\text { Nilai }\end{array}$ & $\begin{array}{l}\text { Katego } \\
\text { ri }\end{array}$ & $\begin{array}{l}\text { Jumla } \\
\text { h (n) }\end{array}$ & $\begin{array}{l}\text { Persent } \\
\text { ase }\end{array}$ \\
\hline $\begin{array}{l}\text { Prokra } \\
\text { stinasi }\end{array}$ & $\mathrm{x}<80$ & Rendah & 16 & $12.6 \%$ \\
$\begin{array}{l}\text { Akade } \\
\text { mik }\end{array}$ & $\begin{array}{l}80 \leq \mathrm{x}< \\
\mathrm{x} \geq 120\end{array}$ & Sedang & 104 & $82 \%$ \\
\hline Jumlah & & & 7 & $5.4 \%$ \\
\hline
\end{tabular}

Berdasarkan kategori pada Tabel 5 maka dapat dilihat bahwa terdapat 16 subjek dengan persentase sebesar 12.6 persen yang memiliki tingkat prokrastinasi akademik rendah, terdapat 104 subjek dengan persentase sebesar 82 persen yang memiliki tingkat prokrastinasi akademik sedang, dan terdapat 7 subjek dengan persentase sebesar 5.4 persen yang memiliki tingkat prokrastinasi akademik tinggi. Berdasarkan penjelasan di atas maka dapat disimpulkan bahwa rata-rata subjek penelitian memiliki tingkat prokrastinasi akademik sedang.

Tabel 6. Perbandingan Data Empirik dan Hipotetik Kontrol Diri

\begin{tabular}{lll}
\hline Variabel & Empirik & Hipotetik \\
\hline Kontrol Diri & 91.24 & 75 \\
\hline
\end{tabular}

Hasil analisis untuk skala kontrol diri diperoleh mean empirik > mean hipotetik yaitu $91.24>75$ maka dapat disimpulkan bahwa kontrol diri pada subjek penelitian lebih tinggi daripada populasi pada umumnya.
Tabel 7. Kategorisasi Kontrol Diri

\begin{tabular}{lllll}
\hline $\begin{array}{l}\text { Variabe } \\
\text { l }\end{array}$ & $\begin{array}{l}\text { Rentan } \\
\text { g Nilai }\end{array}$ & $\begin{array}{l}\text { Kategor } \\
\mathrm{i}\end{array}$ & $\begin{array}{l}\text { Jumla } \\
\mathrm{h}(\mathrm{n})\end{array}$ & $\begin{array}{l}\text { Persen } \\
\text { tase }\end{array}$ \\
\hline $\begin{array}{l}\text { Kontrol } \\
\text { Diri }\end{array}$ & $\begin{array}{l}\mathrm{x}<60 \\
60 \leq \mathrm{x} \\
\end{array}$ & $\begin{array}{l}\text { Rendah } \\
<90\end{array}$ & - & - \\
& $\mathrm{x} \geq 90$ & Tinggi & 72 & $56.6 \%$ \\
\hline Jumlah & & & 127 & $100 \%$ \\
\hline
\end{tabular}

Berdasarkan kategori pada Tabel 7 maka dapat dilihat bahwa tidak ada subjek yang memiliki kontrol diri rendah, terdapat 55 subjek dengan persentase sebesar 43.4 persen yang memiliki kontrol diri sedang, dan terdapat 72 subjek dengan persentase sebesar 56.6 persen yang memiliki kontrol diri tinggi. Berdasarkan penjelasan di atas, dapat disimpulkan bahwa rata-rata subjek penelitian memiliki kontrol diri tinggi.

Tabel 8. Korelasi Antara Kontrol Diri dengan Prokrastinasi Akademik

\begin{tabular}{lll}
\hline Analisis & $\begin{array}{l}\text { Pearson } \\
\text { Correlation }\end{array}$ & $\begin{array}{l}\text { Signifikansi } \\
(\mathrm{p})\end{array}$ \\
\hline Korelasi & -.698 & 0.000 \\
\hline
\end{tabular}

Berdasarkan hasil analisis korelasi antara kontrol diri dengan prokrastinasi akademik, diperoleh koefisien korelasi product moment sebesar -.698 dengan sig sebesar 0.000 ( $\mathrm{p}<0.05)$. Hal ini menunjukkan bahwa adanya korelasi negatif antara kontrol diri dengan prokrastinasi akademik sehingga dikategorikan hubungan yang cukup kuat (Priyatno, 2011). Dari hasil perhitungan tersebut, maka hipotesis yang diajukan dalam penelitian ini menunjukkan ada hubungan negatif antara kontrol diri dengan prokrastinasi akademik diterima, dan dapat dinyatakan bahwa ada hubungan negatif antara kontrol diri dengan prokrastinasi akademik. 
Tabel 9. Model Summary Sumbangan Efektif

\begin{tabular}{|c|c|c|}
\hline $\begin{array}{ll}\text { Mo } & \mathrm{R} \\
\text { del } & \end{array}$ & $\begin{array}{l}R \\
\text { Square }\end{array}$ & $\begin{array}{l}\text { Adjusted } R \\
\text { Square }\end{array}$ \\
\hline
\end{tabular}

\begin{tabular}{lllll}
\hline 1 & $.698 \mathrm{a}$ & .487 & .483 & 11.067 \\
\hline
\end{tabular}

Berdasarkan Tabel 9 Model Summary Sumbangan Efektif di atas, dapat disimpulkan dalam penelitian ini diperoleh koefisien determinasi $R$ Square $\left(\mathrm{R}^{2}\right)$ sebesar 0.487. Berdasarkan hasil tersebut, dapat disimpulkan bahwa sumbangan 48.7 persen kontrol diri mempengaruhi prokrastinasi akademik dan selebihnya 51.3 persen dipengaruhi oleh faktor lain, seperti efikasi diri, dukungan sosial orang tua, konsep diri, motivasi belajar dan regulasi diri.

Hasil utama yang diperoleh dari penelitian ini, yakni terdapat hubungan hubungan negatif antara kontrol diri dengan prokrastinasi akademik dimana $r$ $=-.698$ dan nilai signifikan $\mathrm{p}=0.000$, artinya semakin tinggi kontrol diri maka akan semakin rendah prokrastinasi akademik, dan sebaliknya semakin rendah kontrol diri maka akan semakin tinggi prokrastinasi akademik.

Hasil penelitian yang menyatakan adanya hubungan antara prokrastinasi akademik sejalan dengan penelitian yang dilakukan oleh Fajarwati (2015), dimana ketika individu yang memiliki self-control yang tinggi berarti mampu mengontrol tindakan pada perilaku yang membuat dirinya berkembang lebih baik dan dapat mempergunakan waktu yang ada sebagaimana mestinya atau sesuai dengan tujuan yang ditetapkan. dengan kontrol diri
Adapun hasil penelitian ini juga sejalan dengan hasil penelitian yang dilakukan oleh Clara, dkk., (2017) terhadap siswa SMA X Tanggerang yang berjumlah 395 siswa. Hasil yang diperoleh dari penelitian ini adalah nilai $t=-10.295$ dengan $p=0.000(p<0.05)$. Nilai $t$ negatif menunjukkan peran yang tidak searah sehingga semakin tinggi self-control subjek maka prokrastinasi akademik subjek akan semakin rendah, sebaliknya semain rendah self-control subjek maka prokrastinasi akademik subjek akan semakin tinggi.

Pada penelitian ini diperoleh koefisien determinasi $R$ Square $\left(\mathrm{R}^{2}\right)$ sebesar 0.487. Berdasarkan hasil tersebut dapat disimpulkan bahwa 48.7 persen kontrol diri mempengaruhi prokrastinasi akademik siswa-siswi di SMA Swasta ARRahman Medan, selebihnya 51.3 persen dipengaruhi oleh faktor lain, seperti efikasi diri, dukungan sosial orang tua, konsep diri, motivasi belajar dan regulasi diri.

Pada penelitian ini menunjukkan bahwa siswa-siswi di SMA Swasta ARRahman Medan, terdapat 16 subjek dengan persentase sebesar 12.6 persen yang memiliki tingkat prokrastinasi akademik rendah, terdapat 104 subjek dengan persentase sebesar 82 persen yang memiliki tingkat prokrastinasi akademik sedang, dan terdapat 7 subjek dengan persentase sebesar 5.4 persen yang memiliki tingkat prokrastinasi akademik tinggi. Berdasarkan penjelasan di atas maka dapat disimpulkan bahwa rata-rata subjek penelitian memiliki tingkat prokrastinasi akademik sedang.

Hasil penelitian ini juga menunjukkan bahwa sumbangan efektif 
yang diberikan 48.7 persen prokrastinasi akademik mempengaruhi kontrol diri dan selebihnya 51.3 persen dipengaruhi oleh faktor lain.

\section{SIMPULAN}

Berdasarkan hasil dan pembahasan yang telah dipaparkan dalam penelitian ini, maka hipotesis dalam penelitian ini adalah ada hubungan negatif antara kontrol diri dengan prokrastinasi akademik pada siswa-siswi di SMA Swasta AR-Rahman Medan dengan korelasi Product Moment (r) sebesar -0.698 dengan p sebesar $0.000(\mathrm{p}<0.05)$, yang artinya semakin tinggi kontrol diri yang dimiliki oleh siswa-siswi, maka prokrastinasi akademik akan semakin rendah, dan sebaliknya jika semakin rendah kontrol diri yang dimiliki oleh siswa-siswi, maka prokrastinasi akademik akan semakin tinggi.

\section{UCAPAN TERIMAKASIH}

Peneliti mengucapakan terimakasih kepada bapak Kepala Sekolah SMA Swasta Ar-Rahman Medan yang telah memberikan izin dan kemudahan dalam proses penelitian. Terima kasih atas segala bantuan, keramahan, dan informasi yang diberikan kepada peneliti.

Peneliti mengucapakan terimakasih kepada Dosen pembimbing dalam penelitian ini yang telah banyak memberikan masukan secara personal dan akademis, meluangkan waktu dan pikiran dalam memberikan penjelasanpenjelasan mengenai jurnal.

Peneliti mengucapkan terimakasih kepada orangtua dan teman-teman yang memberikan dukungan dan semangat dalam pengerjaan jurnal. Dan juga kepada siswa-siswi yang telah meluangkan waktunya untuk mengisi skala yang telah diberikam oleh peneliti.

\section{DAFTAR PUSTAKA}

Afriyeni, N., \& Winarno, H. M. (2014). Hubungan antara Efikasi Diri dengan Prokrastinasi Akademik pada Siswa Kelas XI SMA Negeri 9 Padang. Jurnal Antropologi Vol. 16 No. 2 Tahun 2014.

Ali, M., \& Asrori, M. (2011). Psikologi Remaja Perkembangan Peserta Didik. Jakarta: Bumi Aksara.

Clara, C., Agoes, D., \& Debora, B. (2017). Peran Selfeficacy dan Self-control terhadap Prokrastinasi Akademik pada siswa SMA (studi pada siswa SMA X Tanggerang). Jurnal Muara Ilmu Sosial, Humaniora, dan Seni Vol. 1 No. 2 Tahun 2017.

Fajarwati, S. (2015). Hubungan antara Self control dan Self efficacy dengan Prokrastinasi Akademik pada mahasiswa BK UNY yang sedang menyusun skripsi. Jurnal Psikologi Prndidikan dan Pendidikan Vol. 8 No. 4 Tahun 2015.

Fitriya., Lukmawati. (2016). Hubungan antara Regulasi Diri dengan Perilaku Prokrastinasi Akademik pada Mahasiswa Sekolah Tinggi Ilmu Kesehatan (Stikes) Mitra Adiguna Palembang. Jurnal Psikologi Islami Volume 2 Nomor 1 Tahun 2016.

Ghufron, M. N., \& Rini, R. S. (2016). Teori-teori Psikologi. Jogjakarta: Ar-Ruzz Media.

Hidayah, N., \& Atmoko, A. (2014). Landasan Sosial Budaya dan Psiologis Pendidikan; terapannya di kelas. Malang: Gunung Samudra.

Khotimah, R. H., Carolina L. R., \& Dany, M. H. (2016) Hubungan antara Konsep Diri Akademik, Efikasi Diri Akademik, Harga Diri dan Prokrastinasi Akademik pada Siswa SMP Negeri di Kota Malang. Jurnal Kajian Bimbingan dan Konseling Vol. 1 No. 2 Tahun 2016.

Nitami, M., Daharnis., Yusri. (2015). Hubungan Motivasi Beljar dengan Prokrastinasi Akademik Siswa. Jurnal Konselor Volume 4 Number 1 March 2015.

Prasetyo, B., \& Jannah, L. M. (2013). Metode Penelitian Kuantitatif Teori dan Aplikasi. Depok: PT. Raja Grafindo Persada.

Priyatno, D. (2011). Buku Saku Analisi Data SPSS. Yogyakarta: Media Kota. 
Purwanti, M., Purwanti., \& Sri. L. (2016). Pengaruh Kontrol Diri terhadap Prokrastinasi Akademik peserta didik kelas X SMA Negeri 1 Sungai Ambawang. Jurnal Pendidikan Vol. 5 No. 8 Tahun 2016.

Safitri, A. (2018). Hubungan Dukungan Sosial Orangtua terhadap Prokrastinasi Akademik dalam menyelesaikan Skripsi. Jurnal Insight Fakultas Psikologi Vol. 14 No. 2 Oktober 2018.

Sagala, S. (2013). Etika dan Moral Pendidikan Peluang dan Tantangan. Jakarta : Kencana.

Sisdiknas. (2014). Undang-undang RI nomor 20 tahun 2003. Bandung: Citra Umbara.

Sugiyono. (2010). Metode Penelitian Kuantitatif, Kualitatif, dan R\&D. Bandung: Alfabeta.

Sumanto. (2014). Psikologi Umum. Yogyakarta: PT. Buku Seru.

Thalib, S. B. (2010). Psikologi Pendidikan Berbasis Analisis Empiris Apikatif. Jakarta: Kencana. 